\title{
BIOLOGIA POPULACIONAL DE Minuca rapax (SMITH, 1870) (DECAPODA, BRACHYURA), NO MANGUEZAL DE CURUPERÉ (CURUÇÁ, PA, BRASIL)
}

\author{
Nauar, A.R. ${ }^{1}$, Paz, C.A. ${ }^{1}$ \& Belúcio, L.F. ${ }^{1}$ \\ ${ }^{1}$ Universidade Federal do Pará (UFPA), Campus Belém, Laboratório de Biologia Aquática. \\ *Autor correspondente: Ibelucio@gmail.com
}

\begin{abstract}
Minuca rapax (Smith, 1870) é uma das mais amplamente distribuídas espécies de caranguejo da costa brasileira, atuando como importante recicladora de matéria orgânica e bioturbadora do solo de manguezais. No entanto, estudos populacionais desta espécie não são comuns na região Norte, onde o clima pode ser um fator chave na dinâmica populacional. A fim de obter dados acerca da biologia populacional da espécie, parâmetros da população estabelecida no manguezal do rio Curuperé (Curuçá-PA) foram estudados durante um ciclo anual (dez/2016 a out/2017). Os animais foram amostrados a cada dois meses por meio da técnica de Captura Por Unidade de Esforço (CPUE), utilizando o esforço de dois coletores durante 15 minutos. A partir de cada animal coletado foram obtidas as medidas de largura da carapaça (LC) e peso (g) que, posteriormente, foram submetidas aos testes estatísticos para obtenção de dados de abundância, razão sexual, sazonalidade e estatística descritiva. Para obtenção de dados de sazonalidade, foram consideradas as estações chuvosa (fevereiro-abril), intermediária (junho-agosto) e seca (outubro-novembro). Foram capturados 318 exemplares, sendo 177 machos, 138 fêmeas e três espécimes com sexo indefinido. A abundância média da espécie foi de 53 indivíduos por período amostral, considerada baixa em relação aos demais manguezais levantados na costa brasileira, e a razão sexual não se desviou significativamente da proporção de 1:1. O tamanho médio da largura da carapaça (LC) dos machos $(6,98 \pm 1,88 \mathrm{~mm})$ foi um pouco superior ao das fêmeas $(6,87 \pm 1,95 \mathrm{~mm})$, mas não houve diferença estatisticamente. Fêmeas ovígeras foram raras, porém encontradas em todos os períodos sazonais. Considerando a sazonalidade, a LC dos machos foi significativamente menor no período seco, enquanto que a LC das fêmeas foi significativamente menor no período chuvoso. A distribuição de frequência da população em classes de tamanho foi bimodal nos meses de abril, agosto e outubro. Estes resultados são fundamentais para o melhor entendimento do ciclo de vida e de outros aspectos da dinâmica de populações e, dessa forma, auxiliar no manejo desta espécie e equilíbrio do ecossistema manguezal.
\end{abstract}

Palavras-chave: Amazônia, estuário, caranguejo, biologia populacional. 